Кужель Е. В. патентний повірений України, рег. № 144 м. Луцьк, Волинська область, Украӥна

Талах Л. О., к.т.н., доцент Луцький національний технічний університет м. Луцьк, Волинська область, Украӥна

DOI: https://doi.org/10.30525/978-9934-26-125-1-12

\title{
ШУМОПОГЛИНАННЯ У БУДІВНИЦТВІ ЯК ЗАСІБ ЕКОНОМІЧНОЇ БЕЗПЕКИ СУБ'ЄКТІВ ГОСПОДАРЮВАННЯ
}

Кращі світові практики та провідні фахівці і науковціекономісти вважають, що будівельна галузь $є$ не тільки індикатором розвитку держави, але й галуззю, що формує майже усю структуру економіки, тому що зазвичай реалізує величезну частку загальних інвестицій. Загальновідомо, що на даний час інвестиційний ринок в економіці України загалом та у галузі будівництва зокрема, $\epsilon$ дуже проблематичним: тому питання інноваційного розвитку будівництва у сьогоденні є складним завданням і викликає потребу у дослідженні вітчизняного і зарубіжного досвіду. Беззаперечною $є$ доцільність твердження, що будівельна галузь країни $\epsilon$ однією 3 важливіших $\mathrm{i}$ одночасно проблемних галузей економіки, зокрема у іiі реальному секторі. Саме вона визначає необхідні для життєдіяльності населення країни умови, які суттєво впливають на соціум. Слід зазначити, що «проблеми галузі будівництва формувалися роками i зумовлені низкою причин фундаментального характеру, незважаючи на пильну увагу усіх рівнів влади та органів самоврядування» [1, с. 214]. 
Дослідженню проблем інноваційного розвитку підприємств будівельного комплексу присвячено багато уваги в роботах вітчизняних вчених-економістів, таких як Кравченко В.I. [2], Норкіна Т.П. [3, с. 55-62] та ін.

3 літературних джерел, присвячених галузі будівництва, де враховано закордонний досвід, виявлено напрям діяльності та досліджень під назвою «новий курс Рузвельта». Цей напрям передбачає розвиток цивільного будівництва, акцентуючи увагу на потребі будівництва доріг та одночасно визначає, що подальший розвиток економіки країни унеможливлюється без інноваційного підходу до будівельної галузі, тому що виробництво вимагає високої якості проектування і реалізації сучасних технологій.

Представлені матеріали присвячені такому сектору будівництва, як звукозахищеність, яка виконує свою пряму функцію, але й надає можливість здійснення економічної безпеки.

Будь-якій людині, що мешкає поблизу шумливих об'єктів, таких як автотраси, залізничні дороги, промислові підприємства добре відомо, що являє собою шум. 3 джерел науково-технічної літератури відомо, що природа шуму полягає у наявності хаотичних негармонійних коливань, які викликають у людини у кращому випадку лише роздратування. Проте вважається, що за санітарними нормами на людину не впливають шуми до 30 ДБ - 3 нічним рівнем та до 40 ДБ - з денним, але при рівні шуму більше 90 ДБ - у людини виникає нервовий розлад і при рівні шуму 100 ДБ людина втрачає слух (одиницею рівня шуму є децибел (ДБ)).

На даний час вже існує багато пропозицій з питань звукозахищеності від шумів, таких як наприклад, будування стін будинків і споруд типу «сендвіч». Такі стінки включають гладкий та перфорований шари, між якими 
розташовують звукопоглинаючий матеріал. Звукові хвилі проходять крізь перфорований шар і потрапляють на м'який шар звукопоголинаючого матеріалу, втрачаючи при цьому свою енергію, чим і забезпечують захист від проникнення звукових хвиль у середовище. Такі конструкції запатентовані, наприклад, у Росії [4].

У сьогоднішньому стані економічного розвитку будівельної галузі особливої уваги набувають процеси шумопоглинання у такому секторі будівництва, як створення невеличких споруд (акустичних кабін) 3 низьким рівнем зашумленості шляхом розробки i виготовлення збірнорозбірних конструкцій для захисту конфіденційної, переважно мовної інформації. При цьому слід особливо відзначити, що такі розробки $є$ дуже потрібними для державних i комерційних структур, коли існує загроза несанкціонованого доступу до мовної інформації конфіденційного характеру. Витік змісту телефонних розмов або мовної інформації стосовно успіхів чи негараздів партнерських переговорів може ускладнити та заподіяти непоправної шкоди фінансовому становищу або надати конкурентові комерційних переваг. Усунення такого роду проблем полягає у створенні і реалізації відповідних технологій, конструкцій та матеріалів для них. Зазвичай згадані об'єкти розробок можуть бути використані при здійсненні соціополітичних та бізнесово-інформаційних заходів з міжнародними включно. На даний час розроблено декілька варіантів проектних рішень достатньо досконалої мобільної акустичної кабіни у формі кабіни-трансформера [5]. Позитивним у такому конструкторському рішенні $є$ те, що задня стінка кабіни прикріплена до інших елементів конструкції за допомогою гофрованої вставки. Зовнішню поверхню гофрованої вставки споряджують звукопоглинаючим хомутом. При потребі збільшити 
внутрішній простір кабіни гофровану вставку розтягують, а хомут зсувають та герметично прикріплюють до конструкцій кабіни на величину збільшеного простору, захищаючи таким чином від шумів внутрішній простір кабіни, і одночасно запобігаючи витоку розмов 3 ii середини. Збільшення внутрішнього простору кабіни здійснюють при потребі проведення групових переговорів. Кабіну споряджують меблями для сидіння, а головне - інженерними комунікативними засобами: інтернет-забезпеченням, безшумною вентиляцією, а також освітленням та джерелами енергоживлення. Двері кабіни обладнують скляною щонайменше тришаровою вставкою типу «триплекс». Для кращого розуміння нової розробки наведені іï схематичні креслення: вигляд кабіни у ракурсі 3/4, та вигляд кабіни збоку.
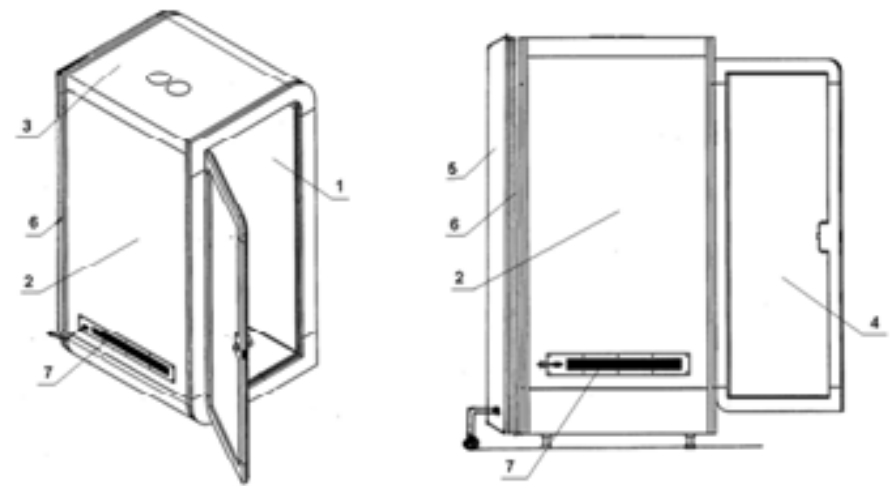

1. Акустична кабіна 2. Бічна стінка 3. Стеля 4. Двері 5. Задня стінка

6. Гофрована вставка 7. Роз'єм для з'єднання з інженерними комунікаційними засобами

Як звукопоглинаючий матеріал для одного 3 шарів панелей кабіни використаний композитний багатошаровий склад, до якого введені додатково порожнинні мікрофібри та базальтовий ровінг. Зовнішня i внутрішня поверхні кабіни декоровані на замовлення користувача. 
Пропонуючи такий варіант проекту виготовлення виробу, авторами проведений збір інформації і аналіз ринку стосовно складу матеріалів, призначених для виробництва шарів обшивки конструкції кабіни. Так, з'ясовано, що використання порожнинних мікрофібр надає додатковий ефект поглинання звукових хвиль, а використання базальтового ровінгу додатковий теплозахист внутрішнього простору кабіни, що сприяє енергозаощадженню. Іншими словами, авторами для оцінки адекватності ринкових умов складу матеріалів, використаних в обшивці акустичної кабіни, проведене польове маркетингове дослідження.

\section{Розроблені сучасні засоби звукопоглинаючих} спеціалізованих будівельних конструкцій спроможна надавати дієвий захист від шумів та забезпечити зручність користування і економічну безпеку.

\section{Література:}

1. Серов О.О. Аналіз проблем та шляхів національного розвитку житлово-комунального господарства України. Проблеми та перспективи розвитку інноваційної діяльності в Україні : Матеріали VIII Міжнародного бізнес-форуму. Київ. 2005 р. С. 214.

2. Кравченко В.І. Глобальні процеси i тенденції розвитку економіки та фінансів України. «Ефективна економіка». 2013. № 3. URL: http://www.economy.nauka.com.ua (дата звернення: 01.09.2021).

3. Норкіна Т.П., Корбун 3.О. Удосконалення управління інноваційним розвитком підприємств будівельної галузі. «Економіка будівниитва і міського господарства». 2013. Т. 9. № 1. С. 55-62.

4. Патент РФ на винахід № 2348750, МПК Е01В 19/00, 2009 p.

5. Кужель Е.В., Сербін С.О., Сербін С.О Засоби звукопоглинання у будівельних конструкціях. «нноваційні технології у будівництві, цивільній інженерії та архітектури» : XIX Міжнародна науково-практична конференція - м. Чернігів, 2021 p. URL: https://pgasa.dp.ua/news/xixmizhnarodna-naukovo-praktychna-konferentsiya-innovatsijni-tehnologiyi-ubudivnytstvi-tsyvilnij-inzheneriyi-ta-arhitekturi/ (дата звернення: 02.09.2021). 